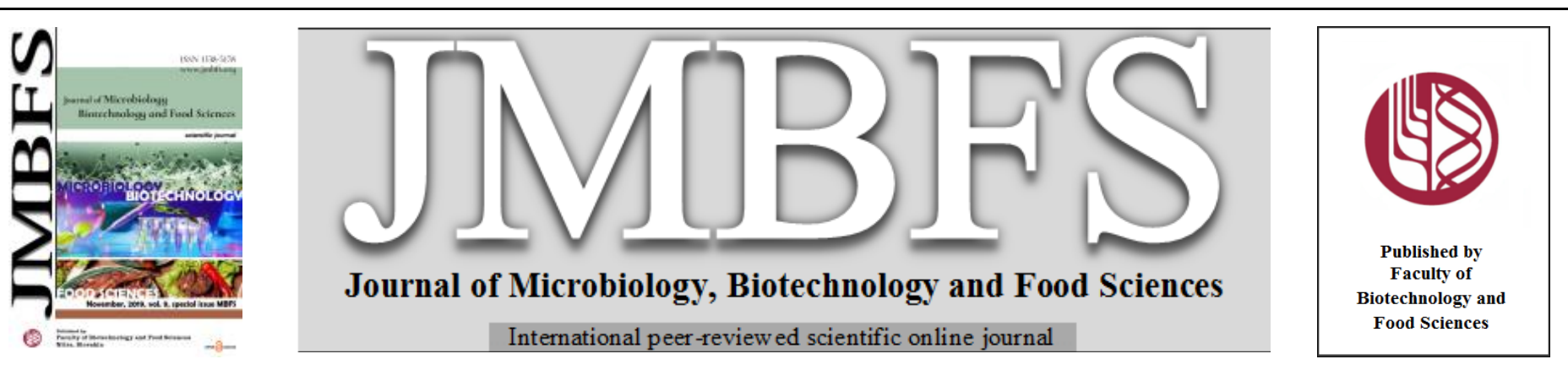

\title{
THE PROFILE OF FATTY ACIDS IN CHICKEN'S MEAT AFTER HUMIC ACID AND PHYTOBIOTICS APPLICATION
}

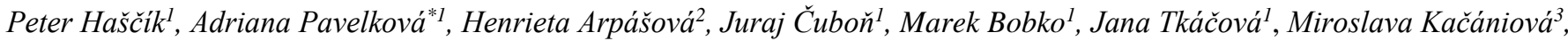 \\ Ondrej Bučko
}

Address(es):

${ }^{1}$ Slovak University of Agriculture in Nitra, Faculty of Biotechnology and Food Sciences, Department of Technology and Quality Animal Products, Tr. A. Hlinku 2, 949 76 Nitra, Slovakia.

${ }^{2}$ Slovak University of Agriculure in Nitra, Faculty of Agrobiology and Food Resources, Department of Poultry and Small Farm Animals, Tr. A. Hlinku 2, 94976 Nitra, Slovakia.

${ }^{3}$ Slovak University of Agriculture in Nitra, Faculty of Biotechnology and Food Sciences, Department of Microbiology, Tr. A. Hlinku 2, 94976 Nitra, Slovakia.

${ }^{4}$ Slovak University of Agriculure in Nitra, Faculty of Agrobiology and Food Resources, Department of Animal Husbandry, Tr. A. Hlinku 2, 94976 Nitra, Slovakia.

*Corresponding author: adriana.pavelkova@uniag.sk

doi: 10.15414/jmbfs.2019.9.special.439-444

\section{ARTICLE INFO}

Received 12.6. 2019

Revised 13.9. 2019

Accepted 14. 9. 2019

Published 8. 11. 2019

Regular article OPEN $\partial_{\text {ACCESS }}$

\begin{abstract}
The aim of the present study was analysed the effect of supplying humic acids separately and humic acids in combination with phytobiotic as garlic and oregano powder on fatty acid (FA) profile of the most valuble parts of Ross 308 chicken carcass. A total of 200 pcs Ross 308 broiler chickens of mixed sex were randomly divided into 4 groups $(\mathrm{n}=50)$ : control group $(\mathrm{C})$ without supplementation, experiment group E1 (2\% humic acids), E2 (80\% humic acids and 20\% garlic powder) and E3 (90\% humic acids and 10\% oregano powder). Fattening period lasted for 42 days and all groups were kept under the same conditions. After slaughter, the FA profiles of breast and thigh samples were determined. In comparison with control group, FA composition of breast and thigh muscle, 7 out of 15 fatty acids was affected $(\mathrm{P} \leq 0.05)$ by dietary supplementation with humic acid (E1), combination of humic acid with garlic powder (E2) and combination of humic acid with oregano powder (E3). The most represented fatty acids in breast and thigh muscle in all experimental groups were oleic acid, palmitic acid and stearic acid. Comparing breast with thigh muscle, one unanticipated finding was that breast contained slightly higher amounts of total SFA (36.41 to $38.47 \%$ in breast vs. 32.63 to $34.20 \%$ in thigh). Besides, breast muscle was found to contain slightly lower proportion of total MUFA (49.01 to 50.27\% in breast vs. 51.29 to $55.50 \%$ in thigh). Breast muscle had higher percentage of total PUFA (11.45 to $11.86 \%$ in breast vs. 7.49 to $9.87 \%$ in thigh). The results of the experiment confirmed that the addition of garlic and oregano powder in combination with humic acids can affect the fatty acid profile of chicken meat.
\end{abstract}

Keywords: broiler chicken, fatty acid, humic acids, garlic, oregano

\section{INTRODUCTION}

There has been an increased interest in recent years in ways to manipulate the fatty acid composition of meat. This is because meat is seen to be a major source of fat in the diet and especially of saturated fatty acids, which have been implicated in diseases associated with modern life (Wood et al., 2003). Among the nutritional aspects of food, lipid content and fatty acid profile are the most important factors (Bostami et al., 2017).

Fat and fatty acids in muscle and adipose tissues are among the major factors that influence meat quality, particularly nutritional value and palatability (Coetzee and Hoffman, 2002). It has been shown that consumers prefer poultry meat and its products for several reasons. Poultry meat is considered healthier owing to its relatively lower fat content compared with other animal meat as beef or pork meats (Leeson, 1999; Bonoli et al., 2007; Brenes and Roura, 2010). Unlike other animal fats, around two third of poultry fat is composed of unsaturated fatty acids, and they are belonged to omega-3 (n-3) and omega-6 (n-6) fatty acids (Shin et al., 2011).

Poultry meat contains significant amounts of monounsaturated fatty acids (MUFA), and only a third of total fat is made up of SFA. Poultry meat also provides a valuable dietary source of long chain n-3 PUFA, including $\alpha$-linolenic acid (ALA, 18:3 n-3), eicosapentaenoic acid (EPA, 20:5 n-3), and docosahexaenoic acid (DHA, 22:6 n-3). In most Western countries, where fish consumption is relatively low, poultry meat may thus represent an important source of n-3 FAs (Marangoni et al., 2015). Compared with other types of meat, n-6 FAs, especially linoleic acid (18:2 n-6) and arachidonic acid (20:4 n-6), can be found mostly in the skin (Marangoni et al., 2015).
Maroufyan et al. (2012) found out 3 n-6/n-3 PUFA ratios in chicken meat from 5.5 to 1.5 . Meluzzi et al. (2009) found out the content of intramuscular fat in the breast from $1.06-1.08 \%$ and in the thigh from 2.99 to $3.48 \%$ and content of PUFA from 35.3 to $37.5 \%$ in the breast muscle and from 32.2 to $35.1 \%$ in the thigh muscle. Chicken meat had a proportion of saturated $36.4 \%$ and polyunsaturated fatty. Chicken meat had a proportion of saturated $36.4 \%$ and polyunsaturated fatty acids $21.3 \%$. Long chain omega-3 polyunsaturated fatty acids (PUFA) eicosapentaenoic and docosahexaenoic were observed only in dark chicken meat 23 mg.100 g ${ }^{-1}$ (Carnevale de Almeida et al., 2006). In addition, the composition of poultry fat is favourable from a nutritional point of view, compared with the low levels of PUFA and high levels of SFA in red meats (Morales-Barrera et al., 2013). The FA profile of poultry meat, however, depends on internal (age, gender, and genotype) and external (temperature, feeding) factors (Starčević et al., 2014).

Performances of broilers during fattening, slaughter characteristics and meat quality are linked to pre-mortal and post-mortal factors. It is considered that diet, as the pre-mortal factor, dominantly impacts the quality of carcasses and meat with more than $30 \%$ (Ristić et al., 2005; Džinić et al., 2011). The fatty acid content of broiler meat depends on the type of diet intake by the birds (Crespo and Esteve-Garcia, 2002).

During the decades, antibiotics have widely been used in poultry production as a growth promoter to enhance the performance. However, in, 2006, EU and many countries have banned using antibiotics as growth promoter in animal nutrition from reason increase antibiotic resistant bacteria, the accumulation of antibiotic residues in animal products and the potential to transfer resistant strains from animals to humans via the food chain (Stanaćev et al. 2011a). This action 
encourages many investigators to search for alternatives to enhance performance (El-Husseiny et al., 2008)

Among possible alternatives are phytogenic feed additives (PFA) which may positively affect poultry health and productivity (Puvača et al., 2015). Many non-therapeutic substitutes (prebiotics (Sarangi et al., 2016), probiotics (Popova, 2017), enzymes (Bedford and Morgan, 1996), bee products as bee pollen (Haščík et al., 2017) and propolis (Saeed $\boldsymbol{e t}$ al., 2017), humic acids (Rath $\boldsymbol{e t}$ al., 2006)), especially plants extracts from a wide variety of herbs, spices and derivatives, have already been used as a feed additive in poultry. These extracts when supplemented to animals diets can play a role in supporting both performance and health status of the animal (Manzanilla et al., 2001; Kostadinovic, 2013).

Herbs and plant extracts used in animal feed is called phytogenics feed additives (also called phytobiotics or botanicals), are defined as compounds of plant origin incorporated into animal feed to enhance livestock productivity through the improvement of digestibility and nutrient absorption, activation of feed intake and secretion of digestive secretions, immune stimulation, antibacterial, coccidiostatic, anthelmintic, antiviral or antiinflammatory activity and inhibition or particularly antioxidant properties (Kamel, 2001; Wenk, 2003; Balunas and Kinghorn, 2005; Athanasiadou et al., 2007)

Recent studies on these compounds have shown some positive effects as antimicrobial (Sari et al., 2006; Wong et al., 2008), but also in other respects such as antioxidant ability and growth promoter function (Wei and Shibamoto, 2007; Krishan and Narang 2014; Zeng et al. 2015) and regulator of the gut flora (Jang et al., 2007) in poultry production. This indicates that plant extracts can be considered as feed additives in poultry production (Muthusamy and Sankar, 2015). Many phytogenic sources to replace antibiotics show promising results not only as an antimicrobial agent.

Phytogenic feed additives are incorporated into diets to improve production performance, and the quality of food derived from those animals (Windisch $\boldsymbol{e}$ al., 2007). The large variety of plant compounds used as PFA are assembled according to their origin and treatment, such as herbs and spices (eg: garlic, anise, cinnamon, coriander, oregano, chili, pepper, rosemary and thyme) but also essential oils or oleoresins (Kamel, 2000). The content of active substances in these products can vary greatly depending on what part of the plant is used (grains, leaves, roots, bark, flowers, or buds), the harvest season and geographica origin (Windish et al., 2008).

The aim of the present study was analysed the effect of supplying humic acids separately and humic acids in combination with phytobiotic as garlic and oregano powder on fatty acid (FA) profile of the most valuble parts of Ross 308 chicken carcass.

\section{MATERIAL AND METHODS}

\section{Animals and experimental design}

The experiment was realized in the experimental poultry station of Slovak University of Agriculture (SUA) in Nitra. Chickens were randomized into four groups, each containing 50 birds. In control group we used complete feed mixture without any additives. Group of chickens E1 was fed a diet containing $2 \mathrm{~kg}$ of preparation Humac Natur per $100 \mathrm{~kg}$ feed mixture. The group marked as E2 was fed a diet containing $1.6 \mathrm{~kg}$ of preparation Humac Natur per $100 \mathrm{~kg}$ feed mixture and $0.4 \mathrm{~kg}$ of garlic powder per $100 \mathrm{~kg}$ feed mixture and group E3 containing combination $1.8 \mathrm{~kg}$ of preparation Humac Natur per $100 \mathrm{~kg}$ feed mixture and 0.2 $\mathrm{kg}$ of oregano leaf powder per $100 \mathrm{~kg}$ feed mixture. The experiment was realized by methology Haščík et al. (2018). Chickens in individual groups were stabled on deep budding, with a maximum occupation of the breeding areas $33 \mathrm{~kg} \cdot \mathrm{m}^{-2}$. During the fattening period, the light regimen based on $24 \mathrm{~h}$ of dark was used. The temperature at the beginning of the experiment was $31-33{ }^{\circ} \mathrm{C}$ and decreased to $20-22{ }^{\circ} \mathrm{C}$ during the experiment. The temperature was maintained using electronic hen-like devices providing radiant heat.

The fattening lasted 42 days. The feeding program included three phases: starter $\left(1^{\text {st }}-21^{\text {st }}\right.$ days of age $)$, grower $\left(22^{\text {nd }}-35^{\text {th }}\right.$ days of age $)$, and finisher $\left(36^{\text {th }}-42^{\text {nd }}\right.$ days of age). Feed and water were supplied ad libitum. The feed mixtures both starter and grower were produced without any antibiotics and coccidiostats. Composition of complete feed mixtures is presented in Table 1.

Humac Natur purchased from Humac s.r.o., Kosice is preparation of humic substances on base of oxihumolit contain min. $62 \%$ humic acids in dry matter, of this $48 \%$ free munic acids in dry matter, minerals and trace elements, carboxymethylcellulose complex with humic substances. Moisture was maximum $11 \%$.

The garlic was added to the feed in the form of finely ground Allium sativum $\mathrm{L}$. bulbs and the oregano was added as dried and finely ground of Oreganum sativum leaves (Vetservis a.s.).

\section{Slaughter and measurements}

At the end of the 42-d feeding period, broilers were weighed and slaughtered at the slaughterhouse of Slovak University of Agriculture in Nitra. After evisceration, the carcasses were kept at approximately $18{ }^{\circ} \mathrm{C}$ for $1 \mathrm{~h}$ post mortem and thereafter carcasses were weighed and stored at $4{ }^{\circ} \mathrm{C}$ until $24 \mathrm{~h}$ post mortem The breast and thigh muscles were separated from each half-carcass for the determination the FA composition. The FA compositions of breast and thigh meats were determined by a direct method for fatty acid methyl ester (FAME) synthesis. The FA composition of the FAME was determined using a Gas Chromatograph (Agilent, 7890A series, USA) equipped with a flame ionization detector and a chiral capillary column (J\&W Scientific, USA).

Table 1 Composition of feed mixtures

\begin{tabular}{|c|c|c|c|}
\hline Ingredients (\%) & $\begin{array}{l}\text { Starter (HYD-01) } \\
\left(1^{\text {st }}-21^{\text {st }} \text { day of age }\right)\end{array}$ & $\begin{array}{l}\text { Grower (HYD-02) } \\
\left(22^{\text {nd }}-35^{\text {th }} \text { day of age) }\right.\end{array}$ & $\begin{array}{l}\text { Finisher (HYD-03) } \\
\left(36^{\text {th }}-42^{\text {nd }} \text { day of age }\right)\end{array}$ \\
\hline Wheat & 34.00 & 34.00 & 35.82 \\
\hline Maize & 36.00 & 41.00 & 38.00 \\
\hline Soybean meal $(48 \% \mathrm{~N})$ & 21.30 & 18.70 & 20.00 \\
\hline Fish meal $(71 \% \mathrm{~N})$ & 3.80 & 2.00 & - \\
\hline Dried blood & 1.25 & 1.25 & - \\
\hline Ground limestone & 1.00 & 1.05 & 1.10 \\
\hline Monocalcium phosphate & 1.00 & 0.70 & 1.00 \\
\hline Fodder salt & 0.10 & 0.15 & 0.20 \\
\hline Sodium bicarbonate & 0.15 & 0.20 & 0.25 \\
\hline Lysine & 0.05 & 0.07 & 0.29 \\
\hline Methionine & 0.15 & 0.22 & 0.29 \\
\hline Palm kernel oil Bergafat & 0.70 & 0.16 & 2.50 \\
\hline Premix Euromix BR 0.5\%* & 0.50 & 0.50 & 0.50 \\
\hline \multicolumn{4}{|l|}{ Nutrient composition $\left[\mathrm{g} . \mathrm{kg}^{-1}\right]$} \\
\hline Linoleic acid & 13.54 & 14.23 & 14.94 \\
\hline Fibre & 30.16 & 29.91 & 30.52 \\
\hline Crude protein & 210.71 & 190.39 & 170.51 \\
\hline MEN (MJ.kg-1) & 12.02 & 12.05 & 12.43 \\
\hline Ash & 24.23 & 19.91 & 38.46 \\
\hline $\mathbf{C a}$ & 8.14 & 7.26 & 7.36 \\
\hline $\mathbf{P}$ & 6.76 & 5.72 & 6.02 \\
\hline $\mathrm{Na}$ & 1.69 & 1.76 & 1.78 \\
\hline
\end{tabular}

*active substances per kilogram of premix: vitamin A 2500000 IU; vitamin E 20000 mg; vitamin D3 800000 IU; niacin 12 000 mg; dpantothenic acid $3000 \mathrm{mg}$; riboflavin $1800 \mathrm{mg}$; pyridoxine $1200 \mathrm{mg}$; thiamine $600 \mathrm{mg}$; menadione $800 \mathrm{mg}$; ascorbic acid $20000 \mathrm{mg}$; folic acid $400 \mathrm{mg}$; biotin $40 \mathrm{mg}$; kobalamin $8.0 \mathrm{mg}$; choline 100000 mg; betaine 50000 mg; Mn 20000 mg; Zn 16000 mg; Fe 14000 mg; Cu 2 $400 \mathrm{mg}$; Co $80 \mathrm{mg}$; I $200 \mathrm{mg}$; Se $50 \mathrm{mg}$.

\section{Statistical analysis}

A statistical analysis was computed using the ANOVA procedures of SAS software with using of Enterprise Guide 4.2 application (version 9.3, SAS
Institute Inc., USA, 2008). Data were reported as mean \pm standard deviation. Statistical significance was calculated using t-test. Differences between the groups were considered significant at $\mathrm{P} \leq 0.05$. 


\section{RESULTS AND DISCUSSION}

The results of experiment with Ross 308 broiler chickens after addition of humic acid and humic acids in combination with garlic and oregano powder, which was aimed at analysed and evaluated fatty acids profile, are presented in Table 2 and

Table 2 The fatty acids profile $\left(\mathrm{g} .100 \mathrm{~g}^{-1}\right)$ of chicken breast muscle (mean $\pm S D$ )

\begin{tabular}{lllll}
\hline Fatty acid\Group & C & E1 & E2 & E3 \\
\hline Lauric (C12:0) & $0.06 \pm 0.01$ & $0.06 \pm 0.01$ & $0.06 \pm 0.01$ & $0.06 \pm 0.01$ \\
Myristic (C14:0) & $1.23 \pm 0.04^{\mathrm{b}}$ & $1.27 \pm 0.03^{\mathrm{ab}}$ & $1.28 \pm 0.04^{\mathrm{a}}$ & $1.26 \pm 0.01^{\mathrm{ab}}$ \\
Palmic (C16:0) & $24.46 \pm 0.07^{\mathrm{b}}$ & $24.23 \pm 0.21^{\mathrm{c}}$ & $24.57 \pm 0.07^{\mathrm{a}}$ & $24.30 \pm 0.19^{\mathrm{bc}}$ \\
Heptadecanoic (C17:0) & $0.36 \pm 0.03$ & $0.34 \pm 0.04$ & $0.36 \pm 0.02$ & $0.34 \pm 0.03$ \\
Stearic (C18:0) & $11.16 \pm 0.20$ & $10.94 \pm 0.34$ & $11.02 \pm 0.24$ & $11.12 \pm 0.16$ \\
Oleic (C18:1 cis) & $40.13 \pm 1.46^{\mathrm{b}}$ & $40.90 \pm 1.76^{\mathrm{ab}}$ & $42.68 \pm 1.66^{\mathrm{a}}$ & $39.14 \pm 2.59^{\mathrm{b}}$ \\
Vaccenic (C18:1 trans-11) & $4.46 \pm 0.15$ & $4.62 \pm 0.15$ & $4.52 \pm 0.15$ & $4.52 \pm 0.09$ \\
Linoleic (C18:2 cis) & $0.05 \pm 0.01$ & $0.05 \pm 0.01$ & $0.05 \pm 0.01$ & $0.05 \pm 0.01$ \\
Conjugated Linoleic (C18:2 n-6) & $0.14 \pm 0.02$ & $0.14 \pm 0.02$ & $0.13 \pm 0.01$ & $0.13 \pm 0.01$ \\
$\alpha$-Linolenic (C18:3 n-3) & $1.94 \pm 0.22^{\mathrm{ab}}$ & $1.81 \pm 0.20^{\mathrm{b}}$ & $1.97 \pm 0.16^{\mathrm{ab}}$ & $2.02 \pm 0.14^{\mathrm{a}}$ \\
Eicosenoic (C20:1 n-9) & $0.53 \pm 0.01^{\mathrm{a}}$ & $0.55 \pm 0.07^{\mathrm{a}}$ & $0.58 \pm 0.05^{\mathrm{a}}$ & $0.45 \pm 0.07^{\mathrm{b}}$ \\
Arachidonic (C20:4 n-6) & $1.79 \pm 0.19^{\mathrm{a}}$ & $1.75 \pm 0.22^{\mathrm{ab}}$ & $1.67 \pm 0.15^{\mathrm{ab}}$ & $1.42 \pm 0.33^{\mathrm{b}}$ \\
Eicosapentaenoic (C20:5 n-3) & $0.11 \pm 0.02$ & $0.12 \pm 0.02$ & $0.10 \pm 0.01$ & $0.10 \pm 0.01$ \\
Docosapentaenoic (C22:5 n-3) & $0.16 \pm 0.01^{\mathrm{a}}$ & $0.14 \pm 0.01^{\mathrm{b}}$ & $0.14 \pm 0.01^{\mathrm{b}}$ & $0.16 \pm 0.01^{\mathrm{a}}$ \\
Docosahexaenoic (C22:6 n-3) & $0.05 \pm 0.01^{\mathrm{a}}$ & $0.04 \pm 0.01^{\mathrm{b}}$ & $0.04 \pm 0.01^{\mathrm{b}}$ & $0.05 \pm 0.01^{\mathrm{a}}$ \\
Omega 3 & $0.64 \pm 0.08^{\mathrm{ab}}$ & $0.60 \pm 0.03^{\mathrm{b}}$ & $0.59 \pm 0.02^{\mathrm{b}}$ & $0.64 \pm 0.01^{\mathrm{a}}$ \\
Omega 6 & $9.91 \pm 0.72$ & $10.14 \pm 0.39$ & $10.01 \pm 0.33$ & $10.33 \pm 0.85$ \\
$\sum$ SFA & $36.96 \pm 0.96^{\mathrm{bc}}$ & $36.41 \pm 1.08^{\mathrm{b}}$ & $38.47 \pm 1.02^{\mathrm{a}}$ & $37.79 \pm 0.86^{\mathrm{ac}}$ \\
$\sum$ MUFA & $49.01 \pm 1.51$ & $49.52 \pm 1.87$ & $50.27 \pm 1.64$ & $49.40 \pm 0.41$ \\
$\sum$ PUFA & $11.45 \pm 0.85$ & $11.73 \pm 0.55$ & $11.86 \pm 0.20$ & $11.84 \pm 0.95$ \\
\hline
\end{tabular}

Note: Values are given as mean $\pm \mathrm{SD}$ (standard deviation); $\mathrm{n}=30 ; \mathrm{C}=$ control group; E1, E2, E3 = experimental groups;

$\mathrm{a,b}=$ means within the same row with different superscripts differ significantly $(\mathrm{P} \leq 0.05)$

Effect of natural feed supplements (humic acid and humic acid in combination with garlic and oregano powder) on fatty acid composition of breast and thigh muscles are shown in Table 2 and Table 3.

In comparison with control group, FA composition of breast muscle (Table 2), 7 out of 15 fatty acids was affected $(\mathrm{P}<0.05)$ by dietary supplementation with humic acid (E1), combination of humic acid with garlic powder (E2) and combination of humic acid with oregano powder (E3). Among SFA, the concentration of myristic acid (C14:0) and palmic acid (C16:0) increased in breast muscle $(\mathrm{P} \leq 0.05)$ when chickens were fed with combination humic acid plus garlic powder (E2; $\left.1.28 \mathrm{~g} .100 \mathrm{~g}^{-1}\right)$ and humic acid $\left(\mathrm{E} 1 ; 24.23 \mathrm{~g} .100 \mathrm{~g} \mathrm{~g}^{-1}\right)$ and humic acid plus garlic powder (E2; 24.57 g.100 g $\left.\mathrm{g}^{-1}\right)$, respectively. Among MUFA, concentration of oleic acid $(\mathrm{C} 18: 1$ cis) was enhanced $(\mathrm{P}<0.05)$ in breas muscle obtained from chickens in E2 (42.68 g.100 $\left.\mathrm{g}^{-1}\right)$ and was decreased $(\mathrm{P} \leq 0.05)$ in the case oleic acid in E3 $\left(39.14 \mathrm{~g} .100 \mathrm{~g}^{-1}\right)$ and eicosenoic acid $(\mathrm{C} 20: 1$ $\mathrm{n}-9)$ in E3 (0.45 g.100 g $\left.\mathrm{g}^{-1}\right)$. The PUFA content of breast muscle was reduced mainly in the form of arachidonic (C20:4 n-6) in E3 (1.42 g.100 g $\mathrm{g}^{-1}$ ) docosapentaenoic (C22:5 n-3) and docosahexaenoic acid (C22:6 n-3) in E1 and E2 $\left(0.14,0.04\right.$, and $0.14,0.04 \mathrm{~g} .100 \mathrm{~g}^{-1}$, respectively). Yet, total amounts of MUFA and PUFA in experimental groups remained unchanged $(\mathrm{P}>0.05)$ compared with control group but content of SFA was increased $(\mathrm{P} \leq 0.05)$ in E2 (38.47 g.100 g $\mathrm{g}^{-1}$ ) compared with control group (36.96 g.100 g $\left.\mathrm{g}^{-1}\right)$. Overall, only 8 (lauric, heptadecanoic, stearic, vaccenic, linoleic, CLA, $\alpha$-linoleic and eicosapentaenoic acids) out of 15 FAs that were detected in broiler breast muscle not differed $(\mathrm{P}>0.05)$ in proportion among the dietary treatments and control group.

Regarding thigh muscle (Table 3 ) significant differences $(\mathrm{P} \leq 0.05)$ in individua FAs among the groups were detected in 7 out of 15 FAs. Feed supplements affected $(\mathrm{P} \leq 0.05)$ a few FA proportions compared with those in control. The reduction $(\mathrm{P} \leq 0.05)$ in SFA was in lauric acid $(\mathrm{C} 12: 0)$ in $\mathrm{E} 1, \mathrm{E} 2$ and $\mathrm{E} 3(0.07$ 0.05 , and 0.06 g.100 g-1, respectively); and stearic acid (C18:0) in E3 (10.54 g. $\left.100 \mathrm{~g}^{-1}\right)$ and increase in myristic acid (C14:0) in E3 (1.35 g.100 g $\left.\mathrm{g}^{-1}\right)$ Among MUFA, content of oleic acid $(\mathrm{C} 18: 1$ cis $)$ was increased $(\mathrm{P} \leq 0.05)$ in thigh muscle of chickens fed with a diet containing humic acid $\left(\mathrm{E} 1 ; 50.91 \mathrm{~g} .100 \mathrm{~g}^{-1}\right)$, vaccenic acid (C18:1 trans-11) in E3 (4.84 g.100 g $\left.\mathrm{g}^{-1}\right)$ and eicosenoic acid (C20:1 n-9) in E1, E2 and E3 (0.74, 0.86 and $0.78 \mathrm{~g} .100 \mathrm{~g}^{-1}$, respectively) compared with control group. The significant increase $(\mathrm{P} \leq 0.05)$ compared with control group was also observed in PUFA proportions, only in $\alpha$-linolenic acid (C18:3 n-3) in E2 $\left(2.07 \mathrm{~g} .100 \mathrm{~g}^{-1}\right)$.

In addition, there was a decrease $(\mathrm{P} \leq 0.05)$ in total SFA in E2 $\left(32.63 \mathrm{~g}^{\circ} 100 \mathrm{~g}^{-1}\right)$ compared with control group (34.20 g.100 g-1). Furthermore, total MUFA was enhanced $(\mathrm{P} \leq 0.05)$ in thigh meat from chickens receiving humic acid $(\mathrm{E} 1 ; 54.45$ g. $\left.100 \mathrm{~g}^{-1}\right)$ and decreased in combination with humic acid plus oregano powder
(E3; $51.29 \mathrm{~g} .100 \mathrm{~g}^{-1}$ ) compared with control group (53.66 g.100 $\left.\mathrm{g}^{-1}\right)$. We found decreasing $(\mathrm{P} \leq 0.05)$ of total PUFA content in E2 $\left(7.49 \mathrm{~g} .100 \mathrm{~g}^{-1}\right)$ compared with control group ( $\left.8.78 \mathrm{~g} .100 \mathrm{~g}^{-1}\right)$.

Comparing breast with thigh muscle, one unanticipated finding was that breast contained slightly higher amounts of total SFA (36.41 to $38.47 \%$ in breast vs 32.63 to $34.20 \%$ in thigh). Besides, breast muscle was found to contain slightly lower proportion of total MUFA (49.01 to $50.27 \%$ in breast vs. 51.29 to $55.50 \%$ in thigh). Not surprisingly, breast muscle had higher percentage of total PUFA ( 11.45 to $11.86 \%$ in breast vs. 7.49 to $9.87 \%$ in thigh), which is in agreement with the results of Shin et al. (2011) or Trembecká et al. (2016).

Regarding the FA profile of chicken meat, total SFA, MUFA, and PUFA proportions (mean of groups) in breasts were similar to those in reference tables of USDA Food Composition Databases (2015) (37, 49 and 12 g. $100 \mathrm{~g}^{-1}$ vs. 56 69

$42 \mathrm{~g} .100 \mathrm{~g}^{-1}$ of fresh meat, respectively), whereas in thighs (referred as a sum of thigh plus drumstick) they were much lower than those reported by USDA Food Composition Databases (2015) (34, 54 and 9 g.100 $\mathrm{g}^{-1}$ vs. 105, 144 and 9.6 g. $100 \mathrm{~g}^{-1}$ of fresh meat, respectively). Such differences may be due to variations in analytical methodologies, diets, and animal breeds.

Milićević et al. (2014), who investigated the impact of chicken meat consumption on cardiovascular risk in the general population, reported that the main FA identified in both breast and drumstick muscles were oleic acid (C18:1 cis) ranged between 37.12 and $39.56 \%$ in breast and between 38.13 and $39.89 \%$ in thigh muscle. In breast muscle, the major SFA was palmitic acid (16:0) and ranged from 21.35 to $28.53 \%$; and the major PUFA was linoleic acid (C18:2 cis n-6) and varied from 10.26 to $24.85 \%$. The FA composition of drumstick muscle showed a slightly higher fraction of linoleic acid (C18:2 cis n-6) in comparison to palmitic acid (16:0) (22.22 to $23.03 \%$ vs. 21.52 to $23.69 \%$, respectively), which is also consistent with our results.

Nonetheless, it is important to keep in mind that even though unsaturated FAs are desirable for human consumption, with increasing degrees of lipid unsaturation, their susceptibility to oxidation increases, which makes meat preservation more difficult (Ladeira et al., 2014), while also in our study, the content of unsaturated fatty acids predominantly decreased in thighs and too breasts, except group E2 and E3 of breast muscle. Azman et al. (2004) reported content of total SFA in thigh muscle of Ross 308 after feeding with soybean oil 42.14 g. $100 \mathrm{~g}^{-1}$, total

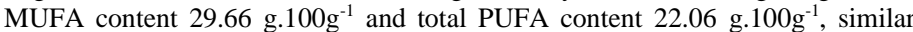
Hrdinka et al. (1996) obtained 48.24 g. $100 \mathrm{~g}^{-1}$ SFA, 40.68 g. $100 \mathrm{~g}^{-1}$ MUFA and 7.12 g. $100 \mathrm{~g}^{-1}$ PUFA in thigh muscle of birds fed with soybean oil, while in our experiment, the measured lower SFA content from $32.63-34.20 \mathrm{~g} .100 \mathrm{~g}^{-1}$, higher

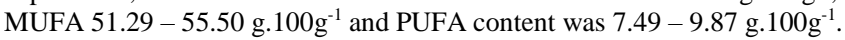


Table 3 The fatty acids profile $\left(\mathrm{g} .100 \mathrm{~g}^{-1}\right)$ of chicken thigh muscle $(\operatorname{mean} \pm S D)$

\begin{tabular}{lllll}
\hline Fatty acidlGroup & C & E1 & E2 & E3 \\
\hline Lauric (C12:0) & $0.08 \pm 0.01^{\mathrm{a}}$ & $0.07 \pm 0.01^{\mathrm{c}}$ & $0.05 \pm 0.02^{\mathrm{b}}$ & $0.06 \pm 0.01^{\mathrm{bc}}$ \\
Myristic (C14:0) & $1.30 \pm 0.02^{\mathrm{b}}$ & $1.29 \pm 0.02^{\mathrm{b}}$ & $1.27 \pm 0.01^{\mathrm{b}}$ & $1.35 \pm 0.01^{\mathrm{a}}$ \\
Palmic (C16:0) & $24.44 \pm 0.11$ & $24.42 \pm 0.11$ & $24.36 \pm 0.13$ & $24.35 \pm 0.20$ \\
Heptadecanoic (C17:0) & $0.29 \pm 0.05$ & $0.27 \pm 0.02$ & $0.25 \pm 0.03$ & $0.26 \pm 0.05$ \\
Stearic (C18:0) & $11.04 \pm 0.11^{\mathrm{a}}$ & $11.09 \pm 0.09^{\mathrm{a}}$ & $11.07 \pm 0.09^{\mathrm{a}}$ & $10.54 \pm 0.30^{\mathrm{b}}$ \\
Oleic (C18:1 cis) & $47.65 \pm 2.28^{\mathrm{b}}$ & $50.91 \pm 2.23^{\mathrm{ac}}$ & $53.13 \pm 3.27^{\mathrm{a}}$ & $43.75 \pm 7.39^{\mathrm{bc}}$ \\
Vaccenic (C18:1 trans-11) & $4.58 \pm 0.09^{\mathrm{b}}$ & $4.56 \pm 0.03^{\mathrm{b}}$ & $4.53 \pm 0.06^{\mathrm{b}}$ & $4.84 \pm 0.10^{\mathrm{a}}$ \\
Linoleic (C18:2 cis) & $0.05 \pm 0.01$ & $0.05 \pm 0.01$ & $0.05 \pm 0.01$ & $0.05 \pm 0.01$ \\
Conjugated Linoleic (C18:2 n-6) & $0.13 \pm 0.02$ & $0.12 \pm 0.01$ & $0.11 \pm 0.01$ & $0.12 \pm 0.01$ \\
$\alpha$-Linolenic (C18:3 n-3) & $1.97 \pm 0.02^{\mathrm{b}}$ & $1.99 \pm 0.12^{\mathrm{b}}$ & $2.07 \pm 0.15^{\mathrm{a}}$ & $1.98 \pm 0.17^{\mathrm{b}}$ \\
Eicosenoic (C20:1 n-9) & $0.61 \pm 0.07^{\mathrm{b}}$ & $0.74 \pm 0.11^{\mathrm{a}}$ & $0.86 \pm 0.14^{\mathrm{a}}$ & $0.78 \pm 0.15^{\mathrm{a}}$ \\
Arachidonic (C20:4 n-6) & $1.45 \pm 0.17$ & $1.39 \pm 0.06$ & $1.28 \pm 0.14$ & $1.44 \pm 0.18$ \\
Eicosapentaenoic (C20:5 n-3) & $0.08 \pm 0.02^{\mathrm{ab}}$ & $0.07 \pm 0.01^{\mathrm{b}}$ & $0.07 \pm 0.02^{\mathrm{b}}$ & $0.10 \pm 0.02^{\mathrm{a}}$ \\
Docosapentaenoic (C22:5 n-3) & $0.13 \pm 0.01$ & $0.13 \pm 0.01$ & $0.13 \pm 0.01$ & $0.14 \pm 0.02$ \\
Docosahexaenoic (C22:6 n-3) & $0.04 \pm 0.01$ & $0.04 \pm 0.01$ & $0.04 \pm 0.01$ & $0.04 \pm 0.01$ \\
Omega 3 & $0.60 \pm 0.04^{\mathrm{b}}$ & $0.63 \pm 0.05^{\mathrm{ab}}$ & $0.69 \pm 0.06^{\mathrm{a}}$ & $0.65 \pm 0.04^{\mathrm{a}}$ \\
Omega 6 & $6.95 \pm 0.81^{\mathrm{a}}$ & $5.84 \pm 0.57^{\mathrm{b}}$ & $5.77 \pm 1.06^{\mathrm{ab}}$ & $6.85 \pm 1.22^{\mathrm{ab}}$ \\
$\sum$ SFA & $34.20 \pm 1.50^{\mathrm{a}}$ & $34.17 \pm 1.07^{\mathrm{a}}$ & $32.63 \pm 0.83^{\mathrm{b}}$ & $33.20 \pm 1.23^{\mathrm{ab}}$ \\
$\sum$ MUFA & $53.66 \pm 0.41^{\mathrm{a}}$ & $54.45 \pm 0.58^{\mathrm{b}}$ & $55.50 \pm 1.78^{\mathrm{ab}}$ & $51.29 \pm 0.77^{\mathrm{c}}$ \\
$\sum$ PUFA & $8.78 \pm 0.86^{\mathrm{ac}}$ & $7.87 \pm 0.87^{\mathrm{bc}}$ & $7.49 \pm 1.03^{\mathrm{b}}$ & $9.87 \pm 1.53^{\mathrm{a}}$ \\
\hline
\end{tabular}

Note: Values are given as mean $\pm \mathrm{SD}$ (standard deviation); $\mathrm{n}=30$; $\mathrm{C}=$ control group; E1, E2, E3 = experimental groups;

$\mathrm{a}, \mathrm{b}=$ means within the same row with different superscripts differ significantly $(\mathrm{P} \leq 0.05)$

Scaife et al. (1994), Hrdinka et al. (1996), Crespo and Esteve-Garcia (2001) and Choi et al. (2010) documented that oleic acid is a major fatty acid of breast, which was confirmed by all groups in our experiment and similar tendency was also retained in the thigh muscle. Disetlhe et al. (2019), who fed chickens with humic acid, found similarly as in our experiment, found increased levels for most PUFAs, and a similar tendency was also found in groups with supplement of garlic and oregano powder. We no found higher differences $(P \geq 0.05)$ in the PUFA content of the breast muscle after the addition of humic acid and garlic or oregano powder, but in the thigh muscle were higher value $(\mathrm{P} \leq 0.05)$ in experimental group with supplementation of the humic acid and garlic powder than in the control as reported by Disetlhe $\boldsymbol{e t}$ al. (2019). In the study Choi $\boldsymbol{e t}$ al. (2010) results show that 3 and 5\% garlic powder or 3\% garlic powder plus $\alpha$ tocopherol supplementation to diets can effectively change the fatty acid composition by increasing or protecting the oxidation of unsaturated fatty acid and total unsaturated fatty acid because palmitic and oleic acids are the main fatty acids of the thigh muscle, what is comparable to our results. There are 2 possible reasons for this phenomenon in the effectiveness of this product: 1) reduction in unsaturated fatty acid and total unsaturated fatty acid using garlic powder and $\alpha$ tocopherol is related to peroxide-scavenging enzyme activity, which could reduce unsaturated fatty acid and total unsaturated fatty acid oxidation and 2) some active components in the garlic powder and $\alpha$-tocopherol may involve desaturase and elongase activities (Kim et al., 2005; Guo et al., 2006). Thus, in terms of beneficial health-related biological properties, it is evident that increasing unsaturated fatty acid and total unsaturated fatty acid contents through dietary manipulation (garlic powder and $\alpha$-tocopherol) could hold promise for the health of consumers (Shahidi, 1996; Belury, 2002). An important acid in chicken meat is also eicosapentanoic acid, which is a precursor of eicosanoids (prostaglandins, tromxoxanes, prostacyclins and leukotrienes) and is important for brain function and vision (Dyall and Michael-Titus, 2008). Its value in breast muscle was increased only after the humic acid addition (E1) and in the thigh muscle after the addition of a humic acid and oregano powder combination. These types of fatty acids are important for human health because they are precursors to the biosynthesis of eicosanoids, which are considered an important bio regulator of many cellular metabolic processes, blood pressure and blood clotting, tissue growth and immune system modulation (Mao et al., 2015) We have confirmed opinion that an increase in n-3 PUFA, especially alfa-linoleic acid in the muscle may cause a substantial decrease in arachidonic acid because of the action of delta-6/5-desturase enzymes in the elongation and desaturation metabolism (Nuernberg et al., 2004). The variation of fatty acid compositions has profound effects on meat quality, because fatty acid composition determines the firmness/oiliness of adipose tissue and the oxidative stability of muscle, which in turn affects flavour and muscle colour. It is well known that high PUFA levels may produce alterations in meat flavour due to their susceptibility to oxidation and the production of unpleasant volatile components during cooking (Wood $\boldsymbol{e t}$ al., 1999). The nutritional properties of meat are largely related to its fat content and its fatty acid composition. In this sense, long-chain n-3 fatty acids, such as C20:5 n-3 and C22:6 n-3 have beneficial health effects, such as reduction in the thrombotic tendency of blood, associated with lower coronary heart disease in humans (EFSA, 2010). Consumption of unsaturated fatty acid, highlighting the PUFA, has shown potential benefits to consumer's health. A higher consumption of saturated fatty acid (SFA) than PUFA associated with the consumption imbalance of n-6/n-3 fatty acid, have been correlated to cardiovascular disease, cancer, inflammatory and auto $\neg$ immune diseases (Simopoulos 2004; Wood et al., 2004). The diet possibly has a significant influence on meat composition, especially broiler chickens. Thus, studies have reported the influence of an animal's diet on fatty acid profile of chicken meat (Bonoli et al. 2007; Gatrell $\boldsymbol{e t}$ al. 2015; Nkukwana et al. 2014; Rymer et al., 2011; Sun et al. 2012)

\section{CONCLUSION}

The addition of garlic and oregano powder in combination with humic acids can affect the fatty acid profile of chicken meat. In thigh muscle, tested supplements decreased SFA content in experimental groups compared to the control group and increased the MUFA content in group with addition of humic acid or combination of humic acid and garlic powder. The PUFA content of the thigh muscle was increased only after the addition of the humic acids with oregano powder compared to the control. The effects of the tested supplements have not been unequivocally confirmed in all fatty acids; therefore we recommend further review to verify their effectiveness.

Acknowledgements: This work was financially supported by the VEGA project 1/0144/19 and KEGA project 027SPU-4/2019.

\section{REFERENCES}

ATHANASIADOU, S., GITHIORI, J., KYRIAZAKIS, I. 2007. Medicinal plants for helminthes parasite control: facts and fiction. Animal, 1(9), 1392-1400 https://doi.org/10.1017/s1751731107000730

AZMAN, M. A., KONAR, V., SEVEN, P. T. 2004. Effects of different dietary fat sources on growth performances and carcass fatty acid composition of broiler chickens. Revue Méd. Vét., 156(5), 278-286.

BALUNAS, M. J., KINGHORN, A. D. 2005. Drug discovery from medicinal plants. Life Sciences, 78(5):431-441. https://doi.org/10.1016/j.lfs.2005.09.012 BEDFORD, M. R., MORGAN, A. J. 1996. The use of enzymes in poultry diets World's Poultry Science Journal, 52(1), 61-68. https://doi.org/10.1079/wps19960007

BELURY, M. A. 2002. Dietary conjugated linoleic acid in health: Physiological effects and mechanisms of action. Annual Review of Nutrition, 22, 505-531. https://doi.org/10.1146/annurev.nutr.22.021302.121842

BONOLI, M., CABONI, M. F., RODRIGUEZ-ESTRADA, M. T., LERCKER, G. 2007. Effect of feeding fat sources on the quality and composition of lipids of precooked ready-to-eat fried chicken patties. Food Chemistry, 101(4), 1327 1337. https://doi.org/10.1016/j.foodchem.2006.03.038

BOSTAMI, A. B. M. R., MUN, H. S., YANG, C. J. 2017. Breast and thigh meat chemical composition and fatty acid profile in broilers fed diet with dietary fat sources. Journal of Food Processing \& Technology, 8(5), 672 https://doi.org/10.4172/2157-7110.1000672

BRENES, A., ROURA, E., 2010. Essential oils in poultry nutrition: Main effects and modes of action. Animal Feed Science Technolology. 158(1-2), 1-14 https://doi.org/10.1016/j.anifeedsci.2010.03.007 
CARNEVAlE DE ALMEIDA, J., PERASSOlO, M. S., CAMARGO, J. L., BRAGAGNOLO, N., JORGE LUIS GROSS, J. L. 2006. Fatty acid composition and cholesterol content of beef and chicken meat in Southern Brazil. Revista Brasileira de Ciencias Farmaceuticas, 42(1): 109-117. https://doi.org/10.1590/s1516-93322006000100012

COETZEE, G., HOFFMAN, L. 2002. Effects of various dietary n-3/n-6 fatty acid ratios on the performance and body composition of broilers. South African Journal of Animal Science, 32(3), 175-184. https://doi.org/10.4314/sajas.v32i3.3744

CRESPO, N., ESTEVE-GARCIA, E. 2001. Dietary fatty acid profile modifies abdominal fat deposition in broiler chickens. Poultry Science, 80(1), 71-78. https://doi.org/10.1093/ps/80.1.71

CRESPO, N., ESTEVE-GARCIA, E. 2002. Nutrient and fatty acid deposition in broilers fed different dietary fatty acid profiles. Poultry Science, 81(10), 15331542. https://doi.org/10.1093/ps/81.10.1533

DISETLHE, A. R. P., MARUME, U., MLAMBO, V., HUGO, A. 2019. Effects of dietary humic acid and enzymes on meat quality and fatty acid profiles of broiler chickens fed canola-based diets. Asian-Australasian Journal of Animal Science, 32(5), 711-720. https://doi.org/10.5713/ajas. 18.0408

DYALL, S. C., MICHAEL-TITUS, A. T. 2008. Neurological benefits of omega3 fatty acids. Neuromolecular Medicine 10(4), 219-235. https://doi.org/10.1007/s12017-008-8036-Z

DZINIC, N., OKANOVIC, DJ., JOKANOVIC, M., TASIC, T., TOMOVIC, V., IKONIC, P., FILIPOVIC. S. 2011. Carssas and breast meat quality of broilers feed with extruded corn. Biotechnology in animal husbandry, 27(4), 1697-1703. https://doi.org/10.2298/bah1104697d

EFSA (European Food Safety Authority) 2010. Scientific opinion on dietary reference values for fats, including saturated fatty acids, polyunsaturated fatty acids, monounsaturated fatty acids, trans fatty acids, and cholesterol. EFSA Journal, 8(3), 1-107. https://doi.org/10.2903/j.efsa.2010.1461

EL-HUSSEINY, O. M., ABDALLAH, A. G., ABDEL-LATIF, K. O. 2008. The influence of biological feed additives on broiler performance. International $\begin{array}{llll}\text { Journal of Poultry } & \text { Science, } & 7 & \text { (9): }\end{array}$ https://doi.org/10.3923/ijps.2008.862.871

GATRELL, S. K., KIM, J., DERKSEN, T. J., O’NEIL, E. V., LEI, X. G. 2015. Creating $\omega-3$ Fatty-Acid-Enriched Chicken Using Defatted Green Microalga Biomass. Journal of Agricultural and Food Chemistry, 63(42), 9315-9322. https://doi.org/10.1021/acs.jafc.5b03137

GUO, Q., RICHERT, B. T., BURGESS, J. R., WEBE, D. M., ORR, D. E., BLAIR, M., FITZNER, G. E., HALL, D. D., GRANT, A. L., GERRARD, D. E. 2006. Effect of dietary vitamin $\mathrm{E}$ and fat supplementation on pork quality. Journal of Animal Science, 84(11), 3089-3099. https://doi.org/10.2527/jas.2005456

HAŠČÍI, P., ARPÁŠOVÁ, H., PAVELKOVÁ, A., BOBKO, M., ČUBOŇ, J., BUČKO, O. 2018. Chemical composition of chicken meat after application of humic acid and probiotic lactobacillus fermentum. Potravinárstvo, 12(1), 694700. https://doi.org/10.5219/943

HAŠČ́́K, P., PAVELKOVÁ, A., BOBKO, M., TREMBECKÁ, L., ELIMAM, I. O. E., CAPCAROVÁ, M. 2017. The effect of bee pollen in chicken diet. World's Poultry Science Journal, 73(3), 643-650. https://doi.org/10.1017/s0043933917000435

HRDINKA, C., ZOLLITSCH, W., KNAUS, W., LETTNER, F. 1996. Effects of dietary fatty acid pettern on melting point and composition of adipose tissues and intramuscular fat of broiler carcasses. Poultry Science, 75(2), 208-215. https://doi.org/10.3382/ps.0750208

CHOI, I. H., PARK, W. Y., KIM, Y. J. 2010. Effects of dietary garlic powder and $\alpha$-tocopherol supplementation on performance, serum cholesterol levels, and meat quality of chicken. Poultry Science, 89(8), 1724-1731. https://doi.org/10.3382/ps.2009-00052

JANG, I. S., KO, Y. H., YANG, H. Y., HA, J. S., KIM, J. Y., KANG, S. Y., YOO, D. H., NAM, D. S.,. KIM, D. H., LEE, C. Y. 2004. Influence of essential oil components on growth performance and the functional activity of the pancreas and small intestine in broiler chickens. Asian-Australasian Journal of Animal Science, 17(3), 394-400. https://doi.org/10.5713/ajas.2004.394

KAMEL, C. 2000. A novel look at a classic approach of plant extracts. Feed Mix The International Journal on Feed, Nutrition and Technology, 9(6), 19-24.

KAMEL, C. 2001. Natural plant extracts: classical remedies bring modern animal production solutions. Feed manufacturing in the Mediterranean region. Improving safety: from feed to food. In Brufau J. (Ed.) Zaragoza: CIHEAMIAMZ, 31-38.

KIM, Y. J., CHANG, Y. H., JEONG, J. H. 2005. Changes of cholesterol and selenium levels, and fatty acid composition in broiler meat fed with garlic powder. Food Science and Biotechnology, 14(2), 207-211.

KOSTADINOVIC, L. J. 2013. Uticaj lekovitog bilja na zdravlje životinja. Monografija. Univerzitet u Novom Sadu, Institut za prehrambene tehnologije, Novi Sad, Srbija,1-86.

KRISHAN, G., NARANG, A. 2014. Use of essential oils in poultry nutrition: a new approach. Journal of Advanced Veterinary and Animal Research, 1(4), 156162. https://doi.org/10.5455/javar.2014.a36
LADEIRA, M. M., SANTAROSA, L. C., CHIZZOTTI, M. L., RAMOS, E. M., MACHADO NETO, O. R., OLIVEIRA, D. M., CARVALHO, J. R. R., LOPES, L. S., RIBEIRO, J. S. 2014. Fatty acid profile, color and lipid oxidation of meat from young bulls fed ground soybean or rumen protected fat with or without monensin. Meat Science, 96(1), 597-605. https://doi.org/10.1016/j.meatsci.2013.04.062

LEESON, S. 1999. The role of nutrition in maintaining quality of poultry products. In T. P. Lyons, \& K. A. Jacques (Eds.), Biotechnology in the feed industry: Proceeding of Alltech's 15th Annual Symposium, Nottingham University press, United Kingdom (pp. 89-102).

MANZANILLA E.G., BAUCELLS F., KAMEL C., MORALES J., PEREZ J.F., GASA J. 2001. Effects of plant extracts on the performance and lower gut microflora of early weaned piglets. Journal of Animal Science, Suppl.1, 473.

MAO, Z., FU, H., NAN, Z., WAN, C. 2015. Fatty acid, amino acid, and mineral composition of four common vetch seeds on Qinghai-Tibetan plateau. Food Chemistry, 171, 13-18. https://doi.org/10.1016/j.foodchem.2014.08.090

MARANGONI, F., CORSELlO, G., CRICELLI, C., FERRARA, N., GHISELLI, A., LUCCHIN, L., POLI, A. 2015. Role of poultry meat in a balanced diet aimed at maintaining health and wellbeing: an Italian consensus document. Food \& Nutrition Research, 59(1), 1-11. https://doi.org/10.3402/fnr.v59.27606

MAROUFYAN, E., KASIM, A., EBRAHIMI, M., LOH, T. C., HAIR-BEJO, M., SOLEIMANI, A. F. 2012. Dietary methionine and n-6/n-3 polyunsaturated fatty acid ratio reduce adverse eff ects of infectious bursal disease in broilers. Poultry Science, 91(9): 2173-2182. https://doi.org/10.3382/ps.2012-02317

MELUZZI, A., SIRRI, F., CASTELLINI, C., RONCARATI, A., MELOTTI, P., FRANCHINI, A. 2009. Influence of genotype and feeding on chemical composition of organic chicken meat. Italian Journal of Animal Science, 8(2): 766-768. https://doi.org/10.4081/ijas.2009.s2.766

MILIĆEVIĆ, D., VRANIĆ, D., MAŠIĆ, Z., PARUNOVIĆ, N., TRBOVIĆ, D. NEDELJKOVIĆ-TRAILOVIĆ, J., PETROVIĆ, Z. 2014. The role of total fats, saturated/unsaturated fatty acids and cholesterol content in chicken meat as cardiovascular risk factors. Lipids in Health and Diseas, 13(1), 42 http://dx.doi.org/10.1186/1476-511x-13-42

MORALES-BARRERA, J. E. GONZALEZ-ALCORTA, M. J., CASTILLODOMINGUEZ, R. M., PRADO-REBOLLEDO, O. F., HERNANDEZVELASCO, X., MENCONI, A., TELLEZ, G., HARGIS, B. M., CARRILLODOMINGUEZ, S. 2013. Fatty Acid Deposition on Broiler Meat in Chickens Supplemented with Tuna Oil. Food and Nutrition Sciences, 4(9), 16-20 https://doi.org/10.4236/fns.2013.49a1003

MUTHUSAMY, N., SANKAR, V. 2015. Phytogenic compounds used as a feed additives in poultry production. International Journal of Science, Environment and Technology, 4(1), 167-171.

NKUKWANA, T. T., MUCHENJE, V., MASIKA, P. J., HOFFMAN, L. C., DZAMA, K., DESCALZO, A. M. 2014. Fatty acid composition and oxidative stability of breast meat from broiler chickens supplemented with Moringa oleifera leaf meal over a period of refrigeration. Food Chemistry, 142, pp. 255261. https://doi.org/10.1016/j.foodchem.2013.07.059

NUERNBERG, K., KUECHENMEISTER, U., KUHN, G., NUERNBERG, G., WINNEFELD, K., ENDER, K., COGAN, U., MOKADY, S. 2002. Influence of dietary vitamin $\mathrm{E}$ and selenium on muscle fatty acid composition in pigs. Food Research International, 35(6), 505-510. https://doi.org/10.1016/s09639969(01)00148-x

POPOVA, T. 2017. Effect of probiotics in poultry for improving meat quality.

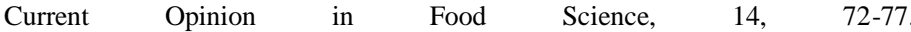
https://doi.org/10.1016/j.cofs.2017.01.008

RATH, N. C., HUFF, W. E., HUFF, G. R. 2006. Effects of humic acid on broiler chickens. Poultry Science, 85(3), 410-414. https://doi.org/10.1093/ps/85.3.410 RISTIĆ, M., DAMME, K., FREUDENREICH P. 2005. Ein" uss phytogener Futterzusatzstoffe auf die Qualität von Ge" ügel" eisch. Meat Technology, 46(12), 51-55.

RYMER, C., HARTNELL, G. F., GIVENS, D. I. 2011. The effect of feeding modified soyabean oil enriched with $\mathrm{C} 18: 4 \mathrm{n}-3$ to broilers on the deposition of $\mathrm{n}-3$ fatty acids in chicken meat. The British journal of nutrition, 105(6), 866-78 https://doi.org/10.1017/s0007114510004502

SAEED, M., ARAIN, M. A., KAMBOH, A. A., MEMON, S. A., UMAR, M. RASHID, M., BABAZADEH, D., EL-HACK, M. E. A., ALAGAWANY, M. 2017. Raw propolis as a promising feed additive in poultry nutrition: trends and advances. Journal of Animal Health and Production, 5(4), 132-142. http://dx.doi.org/10.17582/journal.jahp/2017/5.4.132.142

SARANGI, N. R., BABU, L. K., KUMAR, A., PRADHAN, C. R., PATI, P. K., MISHRA, J. P. 2016. Effect of dietary supplementation of prebiotic, probiotic, and synbiotic on growth performance and carcass characteristics of broiler $\begin{array}{llll}\text { chickens. } & \text { Veterinary } & \text { 313-319. }\end{array}$ https://doi.org/10.14202/vetworld.2016.313-319

SARI, M. , BIONDI, D. M., KAÂBECHE, M., MANDALARI, G., D'ARRIGO, M., BISIGNANO, G., SAIJA, A., DAQUINO, C., RUBERTO, G. 2006. Chemical composition, antimicrobial and antioxidant activities of the essential oil of several populations of Algerian Origanum glandulosum Desf. Flavour and Fragrance Journal, 21(6), 890-898. https://doi.org/10.1002/ffj.1738 
SAS. 2008. 9.3 Enhanced Logging Facilities. Cary, NC: SAS Institute Inc.

SCAIFE, J. R., MOYO, J., GALBRAITH, H., MICHIE, W., CAMPBELL, V.

1994. Effect of different dietary suplemental fats and oils on the tissue fatty acid composition and growth of female broilers. British Poultry Science, 35(1), 107 118. https://doi.org/10.1080/00071669408417675

SHAHIDI, F. 1996. Natural antioxidants: An overview. Pages 1-12 in Natura Antioxidants: Chemistry, Health Effects and Applications. F. Shahidi, ed AOCS Press., Champaign, IL

SHIN, D., KAKANI, G., KARIMI, A., CHO, Y. M., KIM, S. W., KO, Y. G., SHIM, K. S., PARK, J. H. 2011. Influence of dietary conjugated linoleic acid and its combination with flaxseed oil or fish oil on saturated fatty acid and n-3 to n-6 fatty acid ratio in broiler chicken meat. Asian-Australisian Journal of Animal Science, 24(9), 1249-1255. http://Dx.Doi.Org/10.5713/Ajas.2011.11109

Simopoulos, A. P. 2004. Omega-6/Omega-3 Essential Fatty Acid Ratio and Chronic Diseases. Food Reviews International, 20(1), 77-90. https://doi.org/10.1159/000073788

STANAĆEV, V., GLAMOČIĆ, D., MILOŠEVIĆ, N., PUVAČA, N., STANAĆEV, V., PLAVŠA, N. 2011. Effect of garlic (Allium sativum L.) in fattening chicks nutrition. African Journal of AgriculturalResearch, 6(4), 943 948.

STARČEVIĆ, K., MAŠEK, T., BROZIĆ, D., FILIPOVIĆ, N., STOJEVIĆ, Z 2014. Growth performance, serum lipids and fatty acid profile of different tissues in chicken broilers fed a diet supplemented with linseed oil during a prolonged fattening period. Veterinarski Arhiv, vol. 84(1), 75-84.

SUN, T., LIU, Z., QIN, L., LONG, R. 2012. Meat fatty acid and cholesterol level of free-range broilers fed on grasshoppers on alpine rangeland in the Tibetan Plateau. Journal of the Science of Food and Agriculture, 92(11), 2239-2243. https://doi.org/10.1002/jsfa.5609

TREMBECKÁ, L., HAŠČÍK, P., ČUBOŇ, J., BOBKO, M., PAVELKOVÁ, A 2016. Fatty acids profile of breast and thigh muscles of broiler chickens fed with propolis and probiotics. Journal of Central European Agriculture, 17(4), 1179 1193. https://doi.org/10.5513/jcea01/17.4.1828

USDA Food Composition Databases. 2015. National Nutrient Database for Standard Reference, release 28. [online] [cit. 2018-01-09]. Available at: $\langle$ https://ndb.nal.usda.gov>.

WEI, A., SHIBAMOTO, T. 2007. Antioxidant activities and volatile constituents of various essential oils. Journal of Agricultural and Food Chemistry, 55(5), 1737-1742. https://doi.org/10.1021/jf062959x

WENK, C. 2003. Herbs and botanicals as feed additives in monogastric animals Asian-Australasian Journal of Animal Science, 16(2), 282-289. https://doi.org/10.5713/ajas.2003.282

WINDISCH, W., KROISMAYR, A. 2007. Natural phytobiotics for health of young piglet and poultry: Mechanisms and application. Journal of dairy science, 90(Suppl. 1), 643-643.

WINDISCH, W.M., SCHEDLE, K., PLITZNER, C., KROISMAYR, A. 2008.

Use of phytogenic products as feed additives for swine and poultry. Journal of Animal Science, 86 (Suppl. 14), 140-148. https://doi.org/10.2527/jas.2007-0459

WONG, S. Y., GRANT, I. R., FRIEDMAN, M., ELLIOTT, C. T., SITU, C. 2008. Antibacterial activities of naturally occurring compounds against Mycobacterium avium subsp. paratuberculosis. Applied and Environmental Microbiology, 74(19), 5986-5990. https://doi.org/10.1128/aem.00981-08 WOOD, J. D., ENSER, M., FISHER, A. V., NUTE, G. R., RICHARDSON, R. I. SHEARD, P. R. 1999. Manipulating meat quality and composition. Proceedings of the Nutrition Society. 58(2), 363-370 https://doi.org/10.1017/s0029665199000488

WOOD, J. D., RICHARDSON, R, I., NUTE, G, R., FISHER, A. V., CAMPO M. M., KASAPIDOU, E., SHEARD, P. R., ENSER, M. 2004. Effects of fatty acids on meat quality: A review. Meat Science, 66(1), 21-32. https://doi.org/10.1016/s0309-1740(03)00022-6

WOOD, J. D., RICHARDSON, R. I., NUTE, G. R., FISHER, A. V., CAMPO, M. M., KASAPIDOU, E., SHEARD, P. R., ENSER, M. 2003. Effects of fatty acids on meat quality: a review. Meat Science, 66(1), 21-32 https://doi.org/10.1016/s0309-1740(03)00022-6

ZENG, Z., ZHANG, S., WANG, H., PIAO, X. 2015. Essential oil and aromatic plants as feed additives in non-ruminant nutrition: a review. Journal of Animal Science and Biotechnology, 6(1), 7. https://doi.org/10.1186/s40104-015-0004-5 